\title{
Preservation of Balinese Arts and Culture through the Gurukula Art Festival as a Media to Increase Tourism in Pasraman Gurukula Bangli
}

\author{
I Gede Dharman Gunawan ${ }^{1}$, I Ketut $\mathrm{Suda}^{2}$, Ni Made Indiani ${ }^{3}$ \\ \{dharman.gunawan@gmail.com, ${ }^{1}$ suda.unhidps@yahoo.co.id ${ }^{2}$, indianimade@gmail.com ${ }^{3}$ \} \\ ${ }^{1}$ Pascasarjana UNHI Denpasar, Bali, Indonesia \\ ${ }^{2,3}$ UNHI Denpasar, Bali, Indonesia
}

\begin{abstract}
This paper discusses the importance of preserving Balinese arts and culture to increase tourism. Culture is a very important element in a community environment which is a way to be able to develop and be sustainable from each generation. From that culture, a work of art is created, which is the heritage of a Nation. Therefore, for the artwork to continue to exist, we as a nation that is cultured and has quite diverse art should keep the preserved of art culture intact. Along with the times, society to be influenced by other cultures compared to the culture of their society. In Maintaining traditional arts without having to be left behind by the development of world art by holding a Culture Arts Competition, Bali Literature Competition, Arts Exhibition, and Cultural Arts Performance. The implementation of the Gurukula Art Festival as a media to increase tourism and as a form of appreciation for the development of Balinese art and culture continue to be preserved without leaving the artistic heritage that is the identity of the community in Pasraman Gurukula Bangli.
\end{abstract}

Keywords: Preservation of Cultural Arts, Gurukula Art Festival, Tourism

\section{Introduction}

Traditional native arts and culture of a region will not be swallowed up by the noise of other foreign cultures. In Bali, people prefer to absorb and understand the values of their arts and culture because that is their national identity. Therefore, to preserve the native arts and culture, an arts festival is necessary to be held for the younger generation to display their artwork. Arts festivals can also be considered as the symbol of the expressions of Balinese people in various spheres of life to build an awareness that art is an essential need [1].

One of the regencies in Bali that develops and utilizes the potential of nature and cultural tourism as tourism objects and attractions are Bangli [2]. Some programs have been implemented to promote those potentials not only by the government but also by many groups, foundations or institutions. One of the institutions is Pasraman Gurukula. It is one of Hindu educational institutions in Bangli that concerns with the development of traditional works of arts and culture in Bali. They have a program called Gurukula Art Festival. This program proposed by Pasraman Gurukula can be considered as an innovation and strategic plan because it focuses on younger generations who are responsible for the Balinese arts and culture in the future. By holding the festival, they hope that it can preserve the Balinese arts and culture created by the ancestors. 
The implementation of the Gurukula Art Festival has another purpose. It is an actualization of the theory of arts and culture taught by the teachers in the teaching and learning process and also a form of assessment for the students. In that festival, the students show various Balinese artwork and culture such as dance, percussion, painting, Balinese literature and others to have public appreciation. There is also a hope that other people or art communities would participate actively in this festival so that Balinese arts and culture will be sustainable and exist. Gurukula Art Festival is a concrete step proposed by Pasraman Gurukula to maintain and keep the existence of Balinese traditional arts. Besides, this festival is also used to develop the younger generation's creativity in terms of art. People believe that this festival can improve the tourism sector in Bangli.

\section{Research method}

This research is qualitative. As the essence of a qualitative approach, two essentials points need to be taken. The first point is doing direct observation and interaction with local people. It is important to be done to get the authentic data. Second, after doing interaction, identification of the language used by people in the society and their interpretation must be taken to get a better understanding [3]. In other words, this research requires direct observations by seeking information from people who can provide appropriate data. Some information from some other sources like books and documents are necessary to support and complete the data. The data are described qualitatively and deductively so that all components of this research can be displayed in a proper way [4].

\section{Results and discussion}

Gurukula Art Festival is held not only for the sake of preserving Balinese arts and culture but also for synergizing Balinese people with their art and culture. It also facilitates people, especially in Pasraman Gurukula to gain experience, learn and develop their talent in arts. It is a way to appreciate the Balinese arts and culture. Moreover, this festival can be a media to introduce the name of Pasraman Gurukula to the others and remind people about the importance of Balinese literature, arts and culture for the next generation [5].

Besides, seminars and workshops should be done regularly and intensively for people or even students in a formal institution to preserve Balinese traditional arts that are usually used for rituals. Besides, being a good model and giving a direction to the younger generation is considered as an important point to be done, especially to strengthen the identity of Hindus [6]. It is also supported by the Balinese government. They have prioritized the development of Balinese arts and culture because they are the identity of Balinese people and also the local genius of Bali in which it can be the biggest attraction for foreigners. To maximize the development of Balinese arts and culture, the Gurukula Art Festival can be used as a solution. There are also several components related to art and culture in Bali that need to have more attention from Balinese people. Those can be described as follows.

First, there is a sound art of Bali known as matembang. It is like singing (Dharma Gita) that is usually used for Hindu rituals or ceremonies such as kidung, kakawin, sloka, phalawakya and gaguritan. Second, painting is one of the visual arts that can be used to express the aspirations of art through hand-scraping on canvas by talented Balinese painters 
who appreciate the beauty of Bali including society, art, nature, and culture. This kind of art is already well-known all over the world. Third, tabuh or Balinese percussion is the form of expression and appreciation of art through striking Balinese musical instruments that are unique and give an attraction to the audiences. As the other Balinese arts, the development of tabuh is also influenced by the values of Hindu. Because of that great influence, tabuh has sacred and profane nuances. Some of leading Balinese percussions are tabuh gong kreasi, tabuh gong gede, semar pagulingan, tabuh gender, tabuh baleganjur and tabuh gambang.

Next, dance is art that is expressed through classical dances, sacred dances and other dances that give a very beautiful, religious appeal and impress every audience and fans of Balinese dance. Dancing is an expression of the human soul through beautiful rhythmic movements [7]. There are three types of Balinese dances. They are creation dances (manukrawa, panyembrahma, cendrawasih, belibis, and kijang kencana), sacred dances (rejang, pendet, baris jojor, baris tumbak, baris presi, baris bedil, baris memedi and topeng sidhakarya) and traditional dances (topeng bondres, arja, sendratari, wayang wong and wayang kulit). The last component is carving art. It can be used to express the value of art through carvings made by Balinese carving artists who put aesthetic values and selfunification value to the paintings. The materials of carving can be wood, rock or other local materials. The carvings are useful for decoration and adding some ornaments of Balinese traditional houses or architecture.

Balinese government has planned some efforts to preserve culture, both in terms of schools and routine performances that can raise the spirit of the younger generation to develop Balinese arts and culture. The development of the tourism sector has some positive and significant effects on culture in Bali. For instance, it can motivate the Balinese artist to be more creative. Therefore, to maintain the interests and make them focus on developing and preserving the culture for the sake of improving the tourism sector, there must be appreciated, the certainty of life, and an organized system [8].

Pasraman Gurukula is one of the religious social entities that carry out the mission of preserving Balinese culture. The children are disciplinarily trained as agents of preserving Balinese culture, then they are taught various knowledge and skills related to Balinese arts and culture, especially traditional arts. Moreover, Balinese culture has three elements in which they are three layers that overlap one another, namely originating in Hinduism, inspiring the custom in a society or powering up traditional institutions and manifesting it in a high-value art. They make the cultural heritage of Bali have a unique religious characteristic [9]. Several factors cause a tourism destination to have some attractive points, including natural resources, climate, culture, history, ethnicity, and ease (accessibility). Those are very influential in increasing the attractiveness of tourism destinations in Bangli.

Besides, to facilitate the movement of tourists to tourism destinations, some efforts should be taken to increase accessibility in the form of transportation infrastructure, transportation facilities, and transportation systems. The tourism sector can stimulate various production sectors as well as provide direct progress to improve transportation infrastructure, encourage the implementation of cleaning programs for cultural facilities and environmental preservation [10]. In developing tourism destinations, it can be focused on building public infrastructure, providing public facilities and developing tourism facilities.

It is not only about facilities and accessibility, but also community development that is considered as an important strategy in developing tourist destinations. Community development includes increasing the capacity of community resources, increasing awareness and role of the community. In terms of community participation, the role of men and women must be balanced because it benefits the development of the tourism sector [11]. The real 
action can be seen from the effort done by Pasraman Gurukula when implementing Gurukula Art Festival to improve the tourism sector in Bangli.

\section{Conclusion}

Some efforts to preserve Balinese arts and culture have been being developed by people. One of the efforts is the Gurukula Art Festival held by Pasraman Gurukula in Bangli. It is also supported by conducting some extra coaching done by arts practitioners, academics and observers of Balinese arts and culture. It is important to be taken to anticipate the extinction and public ignorance about the existence of Balinese arts and culture. Moreover, there will be some challenges and obstacles faced by Balinese people in the future. Therefore, there must be some innovative and creative ideas proposed by various levels of society. The government also needs to support those ideas because the Balinese arts and culture have some important roles. They can be media to dynamize the values of Hinduism and increase the tourism potentials in Bangli. By holding the Gurukula Art Festival, Balinese arts and culture will exist and the tourists flock to Bali to see the uniqueness of the Island of the Gods.

\section{References}

[1] Sukarma, I. W. "Pengembangan Kearifan Lokal Seni Budaya Melalui Pendidikan Berbasis Banjar di Bali”. Proceeding of International Conference on Art, Language, and Culture. 2019.

[2] Andriyani, A. A. I., Edhi M., and Muhamad M. "Pemberdayaan Masyarakat Melalui Pengembangan Desa Wisata Dan Implikasinya Terhadap Ketahanan Sosial Budaya Wilayah (Studi Di DesaWisataPenglipuran Bali)". Jurnal Ketahanan Nasional 23.1, pp. 1-16, 2017.

[3] Zuriah, N. "Metodologi Penelitian Sosial dan Pendidikan". Bumi Aksara, 2005.

[4] Subagia, I. N. "Keberadaan Pasraman sebagai Penguatan Budaya Lokal Dikaitkan Dengan Peraturan Pemerintah Nomor 55 Tahun 2007”. Vidya Samhita: Jurnal Penelitian Agama 2.2, pp. 31-68, 2017.

[5] Anugrah, K, and I. W. Sudarmayasa. "Pembangunan Pariwisata Daerah Melalui Pengembangan Sumber Daya manusia di Gorontalo". Jurnal Master Pariwisata (JUMPA) 2017.

[6] Sudana, I. W. "Pelestarian Kesenian Tradisional: Pembinaan Tari Baris Gede Di Pesraman Gurukula, Kabupaten Bangli”. Jurnal Ngayah 2.2, pp. 22-34, 2011.

[7] Dalem, A. A. G. A. P. “Aktivitas Komunikasi Kelompok Dalam Melestarikan Seni dan Budaya Bali di Kalangan Sekaa Teruna Dharma Putra Banjar Antungan Blahbatuh Gianyar". Jurnal kajian Ilmu Komunikasi 11.2, 2015.

[8] Budiasih, N. M. "Pengembangan Konsep Pariwisata Untuk mempertkuat Fondasi Pelestarian Budaya dan Spiritual Bali”. Pariwisata Budaya: Jurnal Pariwisata Budaya dan Agama 3.1, pp. 83-89, 2018.

[9] Picard, M. "Bali: Pariwisata Budaya dan Budaya Pariwisata". Kepustakaan Populer Gramedia, 2006. 
[10] Setiawan, N. A. "Strategi Promosi dalam Pengembangan Pariwisata Lokal di Desa Wisata Jelekong". Trikonomika 13.2, pp. 184-194, 2017.

[11] Suardana, I. W. "Pemberdayaan Perempuan di Kawasan Kuta Sebagai Upaya Peningkatan Kualitas Pariwisata Bali”. Faculty of Tourism of Udayana University, 2010. 